\title{
LOCAL MONEY - A RESPONSE TO THE GLOBALISATION OF CAPITAL?
}

\author{
Michael Pacione \\ Department of Geography, University of Strathclyde, Glasgow, United Kingdom
}

Manuscript received October 4, 2011

Revised version October 31, 2011

\begin{abstract}
Pacione M., Local money - a response to the globalisation of capital? Quaestiones Geographicae 30(4), Bogucki Wydawnictwo Naukowe, Poznań 2011, pp. 9-19. DOI 10.2478/v10117-011-0033-x, ISBN 978-83-62662-88-3, ISSN 0137-477X.

AвSTRACT. In response to the global financial crisis of 2007, a number of central banks used quantitative easing to address the collapse of confidence and credit. This involved increasing the liquidity of the financial system by creating new money. It is suggested that similar strategies of 'printing money' in the form of local currencies may be of value for local communities confronting the challenges of economic globalisation. This paper identifies the local impacts of economic globalisation, examines the underlying causes of the global financial crisis, explains the nature of money, and illustrates the goals and different forms of local money. Finally, the potential value of local currencies as a response to the globalisation of capital is assessed.
\end{abstract}

KEY WORDS: local money, complementary currencies

Michael Pacione, Department of Geography, University of Strathclyde, Glasgow G1 1XN, United Kingdom; e-mail: m.pacione@strath.ac.uk

\section{Introduction}

Uneven development is an inherent characteristic of the globalisation of capitalism which stems from the propensity of capital to flow to locations which offer the greatest potential return. The differential use of space by capital in pursuit of profit creates a mosaic of inequality at all geographic scales, from global to local. At any one time certain countries, regions, cities and localities will be in the throes of decline as a result of the retreat of capital investment, while others will be experiencing the impact of capital inflows. The effects of this form of 'casino capitalism' (Strange 1986) on local economies and communities not viewed as profitable spaces by capital can be traumatic (Pacione 2009). This is an inevitable outcome of the global dominance of the capitalist economic system with its ethic of competitive individualism and drive to accumulate. However, when the 'normal business' of the capitalist economic system is disrupted by crisis, the uneven economic and social consequences are amplified. The power of money circulating within the global financial system and the consequence of a breakdown in the flow of capital was demonstrated dramatically by the global financial crisis in 2007 . The shockwaves of the crisis of capital that started in the USA spread around the world to impact on governments, businesses, and local communities, 
accentuating the social and economic challenges confronting people and places marginal to the capitalist development process.

In response to the financial crisis, a number of central banks, including those in the USA and UK, have employed the financial mechanism of quantitative easing to address the collapse of confidence and credit in the wake of the global financial crisis. This involves increasing the liquidity of the financial system by creating 'new money'. The central premise of this paper is that similar strategies of 'printing money' may be of value for local communities confronting the challenges of economic globalisation.

The paper is organised into six main parts apart from the introduction. In part 2 we establish the context for the discussion of local money by outlining briefly the local impacts of economic globalisation. Part 3 considers the rise of megabyte money and examines the underlying causes of the global financial crisis of 2007. Part 4 explains the nature of money. In part 5 the goals and benefits of local currencies are identified. In part 6 the distinction between national and local currency is discussed before proceeding to an analysis of different forms of local currency. Finally, in the concluding section the potential value of local currencies as a response to the globalisation of capital is assessed.

\section{The local impact of economic globalisation}

Globalisation is a highly uneven set of processes whose impact varies over space, through time, and between social groups. The unevenness of globalisation is apparent at all levels of society. At the world scale it is seen in the disparities between booming and declining regions, and at the urban scale in the social polarisation between affluent and marginalised citizens.

The uneven penetration of globalisation is a question not simply of which institutions, industries, people and places are affected, but also of how they are affected. Local people and places may be overwhelmed and exploited by the forces of globalisation, or they may seek to resist, adapt or turn globally induced change into an opportunity. Resistance is a common response in which global forces are mediated at lower spatial scales. During the 1980s, mass protests were held in a number of Third World cities in an effort to resist the imposition of economic austerity measures by the International Monetary Fund (as a response to the burgeoning Third World debt crisis). Frequently, however, people and organisations must acquiesce and adapt to global forces. The proliferation of clothing sweatshops in Los Angeles and New York City during the 1980s, for example, was an attempt by local manufacturers to maintain their competitiveness in world markets. Fundamentally, the adverse impacts of global economic forces come to ground at the local level and are manifested in geographies of disadvantage within cities (Pacione 2004).

The problems of poverty and deprivation experienced by people and places marginal to the capitalist development process have intensified over recent decades. In the UK, during the 1980s poverty increased faster than in any other member state of the European Community so that by the end of the decade one in four of all poor families in the Community lived in Britain (Pacione 1997a). By 2001 the wealthiest 1 per cent of the UK population owned 23 per cent of all wealth (compared with 21 per cent in 1976), while the poorest 50 per cent of the population owned 5 per cent of the nation's wealth (compared with 8 per cent in 1976). Similarly, the population living in poverty in the USA has also increased since the late 1970s, with 13 per cent below the official poverty line in 1980 and 15 per cent in 1993 (Shaw-Taylor 1998). In the West, most of the disadvantaged live in cities, large areas of which have been economically and socially devastated by the effects of global economic restructuring, the deindustrialisation of the economy, and ineffective urban policies. Urban areas and central cities in particular contain disproportionate rates of social and economic problems associated with poverty and deprivation.

It is important to recognise, however, that globalisation does not lead automatically to the disintegration of local life. Individuals can either disembed themselves from a locality by operating within a global milieu or embed themselves by attachment to a particular place. Neither condition is exclusive. The reflexive nature of the global-local relationship is evident especially in 
the world of international finance, where the disembedded electronic space of the international financial system actually compels embedded social relations in specific locations (such as the City of London), to facilitate discussion of new financial products and engaging in inter-personal exchanges of information. More generally, in the place-bound daily lives of most people, particularly those outside the mainstream of advanced capitalism, globalisation may promote a search for local identity in a mobilised world (Eade 1997). One local response to the globalisation of capitalism is the creation and circulation of a local currency.

\section{Megabyte money and the 2007 financial crisis}

Money was invented to replace barter in the exchange of goods and services. For centuries, money has served as a medium of exchange, a common unit of account and a store of value. In recent decades it has also become a commodity to be bought and sold. This new function of money was created by the US government's decision in 1971 to take the dollar off the gold standard and allow exchange rates to float in the international markets. With the collapse of the Bretton Woods agreement, which had pegged the value of the US dollar to gold (and other major currencies to the dollar at a fixed exchange rate), the value of national currencies was determined only by investor confidence. In 1995 US\$1.2 trillion was exchanged every day in the currency markets, and 95 per cent of all currency transactions in the world are motivated by speculation.

The advent of money as a commodity has decoupled the 'real economy' from the 'money economy', the first and smaller of the two being where products are made, trade is conducted, research carried out and services are rendered. The other, far larger, money economy is concerned with speculation and the exchange of credits and debts. For the money markets, the long-term economic health of the real economy is incidental to the primary goal of electronic speculators, which is to realise a profit during the working day. This short-termism can have an adverse effect on the operation of the real economy, with companies affected by rising interest rates, increasing commodity prices and declining exports due to a strong domestic currency. In extreme circumstances, companies and their jobs may be undermined, regardless of performance, because of sudden changes in the financial environment in which they operate.

The financial crisis of 2007 was triggered by a liquidity shortfall in the US banking system that resulted in the collapse of large financial institutions, the bailout of banks by national governments, and downturns in stock markets around the world. In many areas the housing market was also affected, leading to evictions and foreclosures. The liquidity crisis contributed to business failures, marked declines in consumer wealth, substantial financial commitments by governments, and a recession second in depth only to the Great Depression of the 1930s. While the causes of the crisis are complex, a major factor was inadequate regulation of financial institutions driven by the capitalist imperative of profit maximisation. Imprudent lending practices engaged in by financial institutions competing for borrowers made credit relatively cheap. In the US one major consequence was a housing boom fuelled in large part by a rapid expansion of mortgage lending with inadequate consideration given to the borrowers' ability to repay loans. In addition, the credit boom, fuelled by large flows of global savings into the US, drove down the returns available on many traditional long-term investments such as Treasury bonds, leading investors to search for alternatives. To satisfy this demand, the financial industry designed complex securities that combined many individual loans, and that involved substantial risks that were ignored or unforeseen at the time. The credit boom began to unravel in early 2007 when the sub-prime mortgage crisis emerged with mortgage delinquencies and defaults rising and a downturn in house prices (Bernanke 2009). Investors responded by withdrawing from a wide range of credit markets, and financial institutions cut back on their lending. In autumn 2008 the failure or near failure of several major financial firms caused many financial and credit markets to freeze up. Declining stock values, a weakened financial system and major difficulties in obtaining credit triggered recession. 
Money is an essential lubricant of the global economy and, as the 2007 financial crisis revealed, when money is in short supply the engine seizes up, with grave consequences for governments, stock markets and local communities faced with growing unemployment, higher taxes, cuts in public services, and reduced welfare regimes. Several central banks responded by employing quantitative easing to increase the money supply. This may be viewed as the electronic equivalent of printing legal tender. The central bank first credits its own account with money it creates $e x$ nihilo (out of nothing). It then purchases financial assets including government bonds, agency debt, mortgage-backed securities and corporate bonds from banks and other financial institutions. The purchases provide the banks with the excess reserves required for them to increase the money supply and, hopefully, stimulate the economy.

The premise posited in this essay is that a similar process of 'printing money' may be applied at the local scale, not, of course, through the counterfeiting of legal tender, but through creation of an alternative complementary currency. The basic contention is that, despite the hyper-mobility of money in the international financial system, the creation of a local currency can facilitate the development of a degree of local autonomy within the framework of a global economy.

\section{The nature of money}

Before discussing the main forms of local currency, it is necessary to first clarify the meaning of money in general. Definitions of money abound (Angell 1930; Dodd 1994; Galbraith 1975). Material definitions focus on what money is and identify the changing nature of money over the centuries from money as a thing such as gold, coinage or paper currency to money as a system created by the computer and telecommunications revolution of recent decades and the freeing of exchange rates (following the departure of the USA from the gold standard in 1971). Functional definitions of money focus on what money does, on its role as a medium of exchange, standard of value, unit of account, and store of value.
Further light is shed on the nature of money, however, by understanding how it is created. For Soddy (1935) money is the nothing you get for something before you can get anything. This aphorism encapsulates the ethereal nature of money. As Reigel (1978: 15) explains, "money simply does not exist until it has been accepted in exchange. Hence two factors are necessary for money creation: a buyer, who issues it, and a seller, who accepts it. Since the seller expects, in turn, to reissue the money to some seller, it will be seen that money springs from mutual interest and cooperative action among traders, and not from authority. That the government can issue money for the people (...) is an utter fallacy. Money can be issued only by a buyer for himself, and he must in turn be a competitive seller to recapture it and thus complete the cycle".

The fundamental defining characteristic of money of all types is user confidence in its redeemability for goods and services. Money is a symbol with no intrinsic value; it maintains its value by trading on what people think of it and on how much confidence they have in the institutions backing it. Significantly for the present discussion, there are in practice no financial or legal barriers to the creation of local money. There are, however, several important differences between local and national currency. The first of these is that while national currency is accepted internationally, local currency can only be used within a restricted area. This geographical constraint should be viewed in a positive light, however, since within a local trading system any spending power input by an individual is likely to return to him/her in the form of increased demand for their services. A second key difference is that national money is relatively scarce because its supply is restricted deliberately for fear of inflation, whereas the supply of a local currency related directly to trade activity is always adequate for its purpose. Thirdly, the external control exerted over the supply of national currency provides the issuing agents with power over those in need of money, whether individuals or local governments. A local currency based on the abundance principle rather than a model of scarcity cannot be an instrument of domination. 


\section{The goals of a local currency}

While the proposal for a local currency marks a significant departure from the forms of money circulating in the international financial system, the concept is far from a novel one - in ancient Egypt, for example, barley was used as a medium of exchange for domestic transactions and silver for international trade (Galbraith 1975). As Jacobs (1984: 158) concluded, modern societies have been persuaded that the elimination of multitudinous currencies in favour of fewer national currencies represents economic progress and promotes the stability of economic life, but "this conventional belief is still worth questioning". The potency of this statement is strengthened by a number of developments in the global political economy, including the creation of new forms of money following the collapse of the Bretton Woods agreement; the increasing separation of the (productive) 'real economy' from the (speculative) 'money economy'; and, in particular, the growth of an international financial system comprising a 'space of flows' with limited attachment to place. A local currency seeks to short-circuit the electron flow of "megabyte money" (Kurtzman 1993) within the international financial system and to re-embed money in specific locales. In this context, Robertson (1989) envisaged a hierarchy of money with a world currency for use in international trade, national currencies for use in national trading, and local currencies for use in local trading, together with regional or continental currencies (such as the Euro).

A local currency has the potential to achieve several objectives. A principal argument in favour of local currencies is that when localities are dependent entirely on national currency as a medium of exchange to facilitate local economic activity, any decline in local competitiveness within the national or international economy can result in a shortage of money in local circulation even for internal economic purposes within the locality. This leads to the situation experienced in many formerly flourishing industrial cities in Europe and North America where local unemployment rises and local assets remain underutilised, while local needs remain unmet. Underlying this anomaly is the shortage of official currency circulating locally as a medium to facil- itate local exchange. This shortfall in the money supply is a direct consequence of the short-term profit-maximisation goals of capitalism and the international mobility of finance capital. It is promoted by the existence of a centralised banking system that operates to redistribute investment capital to high-profit low-risk areas, which, in general, means from poorer to richer areas, thereby accentuating regional socio-economic disparities. A local currency can stem the leakage of money out of the local economy. In addition, use of a local currency retains local control over investment decisions which is lost even when local capital is 're-imported' via distant financial institutions. A local currency also encourages individuals and businesses to support each other rather than buying from outside the community, and can help to meet the credit needs of small businesses, thereby stimulating the local economy and diversifying its economic base. Another related advantage is that a local currency can generate local employment by overcoming the mismatch between the shortage of money and the excess of work required to be done in any local economy. In general, people will be prepared to work in return for a local currency in which they have confidence - that is, for a currency that can be used to pay for the material necessities of life. We shall return to this point later in the discussion.

A second principal advantage of a local currency lies in its ability to reduce dependency on transfer payments in the form of central government welfare benefits, economic grants and annual council spending budgets. Since the late 1970s, in the UK transfer payments from central to local government have failed to maintain their real value as a result of growing demand and constraints on resources available. Furthermore, by inculcating a dependency culture, transfer payments do little to promote the development of local human capital. Rather than looking to a continued flow of transfer payments to maintain the local economy, dependent cities and regions should pursue development of 'import-replacing' goods and services. As indicated above, introduction of a local currency could play a central role in promoting such developments by retaining spending power within the locality and fostering the growth of indigenous enterprise. 
A final advantage of a local currency is that, in certain forms, it can facilitate a non-inflationary monetary system. Inflation is a major problem of centrally-issued currency whereby the operation of the market mechanism can devalue the currency through oversupply. Under such conditions the sellers of goods and services seek to protect their income by raising prices. Lenders increase their interest rates, thereby raising the cost of credit, which can have an adverse effect on business survival or development. As we shall see below, some forms of local currency eschew the use of interest, while others employ the concept of negative interest to maintain the money supply.

\section{Forms of local currency}

A review of the historical and contemporary literature reveals the existence of a large number of local currency systems. For analytical purposes these may be grouped into two major categories of private and public schemes.

\subsection{Privately issued local currency}

Modern attempts by individuals or private agencies to set up systems to enable exchange to take place without the use of official currency date from the seventeenth century when a Quaker, John Bellers, proposed that unemployed workers be paid in a 'local currency' of labour notes for goods which they produced with materials supplied by the system's central office. The office was to recover its notes by selling the goods either to the workers or to others who had accepted notes from the workers (for example in payment for food or rent). A similar scheme was introduced by the philanthropist Robert Owen, who opened his National Equitable Labour Exchange in London in 1832, and by the French socialist Pierre-Joseph Proudhon, who established a People's Bank in Paris in 1849. However, none of these schemes survived for more than a few years.

Given that one of the chief goals of a local currency is to offset a shortage of national currency, it is unsurprising that a large number of 'local money' initiatives arose during the years of the Great Depression. Typical of these was the Larkin Merchandise Bond issued in 1933 by Larkin and Company of Buffalo, New York. The bonds were used to pay employees of the company and were accepted in any Larkin retail outlet in the USA, as well as by many other businesses. While the bonds were in circulation, the original $\$ 36,000$ issue was turned over sufficiently to facilitate the sale of $\$ 250,000$ worth of merchandise. This and other scrip issues gradually declined towards the end of the Depression as official currency became more readily available. However, this does not diminish the proven success of local money in stimulating a local economy (Fisher 1933).

The practical benefits of a local currency were also demonstrated in 1931 in the Bavarian village of Schwanenkirchen when the new owner of a defunct coal mine re-opened it by paying the miners in local currency (wara) which he had arranged could be spent in village shops. The local currency eventually found its way back to the mine owner through the purchase of coal. The significance of this system is that if reichsmarks had been used instead of wara, the enterprise would not have been possible since the national currency would either have been hoarded for use at a future time or would have been dispersed throughout the country with a correspondingly limited impact on the local economy. Fears of an inflationary spiral due to the success of the local currency led the German government to proscribe the use of wara. Consequently, the coal mine in Schwanenkirchen closed and the miners returned to unemployment and the local economy to stagnation.

In recent years privately-issued local currencies have been employed in several US communities in order to support local businesses and retain purchasing power in the local economy. Since 1989 several firms in the town of Great Barrington, Massachusetts have issued a discount scrip form of local currency as a means of raising capital which was unavailable from formal banking sources. A simple example serves to illustrate the principle. When refused a bank loan of $\$ 4,500$ to finance a move to new premises, the owner of a popular delicatessen printed his own currency (Deli Dollars) and sold them to customers in order to raise the capital he needed to stay in business. 
He sold a ten deli dollar note for US\$9 redeemable at his new business for $\$ 10$ worth of sandwiches. The owner generated sufficient funds from the sale of 500 notes to finance the relocation, the debt to be repaid in sandwiches rather than federal dollars. In addition to the advantage acruing to the business, individual participants in the scheme obtain a discount on future purchases (provided the business stays afloat and implements the redemption programme), and the psychological satisfaction from helping a local firm. The community at large benefits from the retention of spending power in the locality and reinforcement of community solidarity. Clearly, this principle can be extended. Similar forms of local currency (for example, related to food producers) could be distributed by voluntary groups to needy families, enabling them to purchase foodstuffs free from the stigmatisation attached to formal welfare programmes.

The major problem of discount scrip is that its success depends on the business enjoying the trust and confidence of its customers. It is not, therefore, normally applicable to start-up ventures. The issue of participant confidence may also affect the transferability of such schemes. While small-town communities may be willing to support the local economy in this way, people in larger-scale urban areas with less ties to local retail outlets and wider opportunities for purchase may have less incentive to buy locally. Solomon (1996), however, views the use of such local currency initiatives as not simply a technique to attract customers to a business but as a means of educating consumers about the importance of local purchasing for the strength of the local economy.

The most successful community-wide local currency system in the USA is the Ithaca Hours scheme based in the town of Ithaca in New York State (Jacob 2004). The local currency, the Ithaca Hour, has a fixed exchange value with national currency of $\$ 10$ (the average hourly value of wages and salaries in the area). By the end of 1995, 250 businesses accepted Ithaca Hours, with some even giving change in federal currency. The smooth operation of the scheme is ensured by the close involvement of the system organisers, who actively recruit useful goods and services to expand the range available and liaise with par- ticipants to ensure they have satisfactory outlets for accumulated Hours. A key role is played by the originator of the scheme, who is employed to oversee operations, a task which includes producing a regular newspaper advertising the goods and services available within the system and organising twice-monthly open meetings of participants to review the operation. The main structural weakness of the Ithaca scheme is the absence of a mechanism to prevent inflation in the event of a surplus of Hours in circulation (which might arise if growth in the formal economy increased the availability of national currency). In practice, decisions on how much local currency to put into circulation are made at regular meetings open to all participants in the scheme. The view of the organisers is that the threat of inflation is minimal since the amount of money provided by the formal economy will never be sufficient to meet the needs of all members of the community, meaning that a local currency will always be in demand. The success of the Ithaca Hours system has stimulated its reproduction in over twenty other places in the USA (Douthwaite 1996).

A different form of privately-issued local currency is the service credits or time dollars scheme designed specifically for the provision of community care services (rather than for the more general revitalisation of a local economy). Time dollars are earned by providing care services at the rate of one time dollar per hour, and can only be spent in buying care for oneself or for friends and relatives. The largest operating time dollar system is in Miami, but by 1994 there were over 150 schemes operating in 30 US states. The time dollar has no monetary equivalent, but is a form of money which enables people to undertake work they would be unlikely to do for a cash payment. (For example, a retired financial consultant might not cut a sick person's lawn for money, but would do it for time dollars). Unlike national currency, the supply of time dollars is not limited by an external agency, being dependent only on the willingness of local people to help each other. In essence, time dollars represent a stimulus to the moral economy that some commentators believe to have been marginalised by the processes of globalisation (Cahn \& Rowe 1992).

The rise of local money systems is not confined to the western world. In Argentina the uneven 
impacts of economic globalisation and introduction of a government programme of privatisation that favoured multi-national corporations led in 1995 to the creation of a network of mutual assistance among the disadvantaged that aimed to promote "the exchange of goods and services without being restricted by access to money" (Pearson 2003: 216). While the system (Red Global de Trueque) began as one of barter, the introduction of a currency transformed it into an alternative money system. By 2001 nodos (clubs) had been established in fourteen provinces and membership had grown to 300,000 . The national government recognised the scheme officially and in 2000 signed an agreement of support to help promote inter-regional exchange via an electronic network. The rapid growth of the system, however, led to 'growing pains', including a plethora of local currencies and doubts over their reciprocal value that led some nodos to refuse to accept the notes of others. By 2004, membership has fallen to 100,000 using mainly decentralised local systems (Greco 2001, Cato 2006).

In the UK the development and growth of local currencies has been related directly to the rapid expansion of local exchange trading systems (LETS) since the idea was introduced from Canada in 1984 (Linton 1986). The principal economic objective of a LETS is to facilitate 'import substitution' in its locality in order to promote a local economy that is less reliant on external sources of goods, services and money. In a LETS, money is a purely local currency which cannot be traded outside the system. It is not commodified as in the formal economy and its value is based on reciprocal trust among members. Additional 'money' is created not by a central bank, but by the users (via demand for goods and services) without affecting the value of the currency (as there is no inflation, since the money supply is related directly to trading activity). Since no interest is charged on 'debts' or paid on 'credit' balances, non-productive finance capital is absent from the LETS system. Neither is profit accumulation an important objective since trade can be engaged in by those in deficit. In essence, and in marked contrast to the formal monetary economy, LETS currency is employed primarily for its use value (as a medium of exchange), not for its exchange value (as a commodity). As Seyfang (1994: 20) states, "LETS currency is not capitalist money". For Dauncey (1988: 51) LETS currency represents "a new kind of money (...) which is immune from international recession, debt charges, supply problems, theft, scarcity and currency fluctuations". There are now over 400 functioning LETS in the UK and, for several observers, the potential of the concept as a source of credit for disadvantaged communities and a mechanism for reducing leakage of resources from a local economy demands further investigation (Pacione 1997b; Thorne 1996; Williams 1996).

\subsection{Publicly issued local currency}

A key factor underlying the soundness and acceptability of a local currency is confidence in its redeemability, which implies confidence in the power, productive capacity and honesty of the issuing body. While such levels of confidence can be generated by private companies (such as Larkin and Company in the USA and Herr Hebecker's mining company in Schwanenkirchen, Germany), currency issued by a public authority, such as a municipal government, is also likely to attract a high level of credibility, particularly if it can be used to pay fees and taxes, and if it is accepted at par with official money.

As we have seen, the original intention of 'Depression scrip' was to provide a temporary supplement to a scarce supply of official currency. However, the permanent use of a local currency can offer the advantage of insulating a local economy, at least partially, from the vagaries and distorting effects of the international financial system. The idea of a local currency alternative to official currency was first proposed by Silvio Gesell (1862-1930), a German merchant, theoretical economist and social activist, who also introduced the concept of "negative interest" designed to increase the supply of money which could function as a medium of exchange rather than as merely a store of value (Gesell 1958). Gesell's ideas were put into practice in 1932 in the Austrian town of Wörgl in response to serious local tax arrears due to high levels of unemployment. The local currency was used to pay half the wages of council staff and because business people knew it could be used to pay taxes, it was accepted in 
return for goods. In fact, local traders took no risk in accepting Wörgl scrip since it was backed by a national currency loan left on deposit in the local savings bank. This allowed any scrip holder to exchange it at any time for $98 \%$ of its face value in national currency. In order to prevent hoarding, the local currency was imbued with a builtin depreciation factor, or negative interest rate. A stamp costing $1 \%$ of the face value of each note had to be purchased each month in order to revalidate it for use during the following month, meaning that holders were encouraged to spend rather than save the local currency. Any local money returned to the bank or paid to the council was immediately put back into circulation in the town. The impact of the auxiliary money on the local economy was striking. In the first month 4,542 schillings of tax arrears were paid, allowing a new public works programme to begin that employed 50 people whose wages were paid wholly in local currency. When other towns expressed interest in issuing a local currency, the Austrian Central Bank, fearing it would lose control over the money supply and hence inflation, took legal proceedings against the Wörgl council and halted the scheme. Nevertheless, the advantages of the local currency were apparent and during the early 1930s more than 300 communities in the USA introduced similar forms of scrip. Fisher (1933) describes a type of scrip proposed for the city of Reading, Pennsylvania in which the note had 52 squares on the reverse, each printed with the date of consecutive Wednesdays in the year after its issue. Before the note could be used, the holder had to affix a special 2-cent stamp in the appropriate square. At the end of the year the sum of $\$ 1.04$ would be built up, allowing the note to be redeemed at par, with 4 cents to cover expenses. In March 1933, however, President Roosevelt banned further scrip issues on the grounds that the US monetary system was moving out of the control of the national government.

The inherent benefits of a publicly issued local currency continue to commend the concept to communities experiencing a shortage of conventional money. In 1985 the Argentinian province of Salta introduced its own unstamped scrip. Public employees and creditors were offered the choice of payment in local currency immediately or in national currency later. Since inflation was rising rapidly, many accepted the new notes (secure in the knowledge that banks would exchange them at par for national currency if necessary). However, to encourage people to circulate the notes rather than exchange them, the local government accepted the currency in payment of taxes, and organised a lottery offering prizes to the holders of notes bearing winning numbers. Shops and businesses rapidly accepted the new money, and the scheme was reproduced by several neighbouring provinces (Greco 1994).

For local governments with an insufficient supply of national currency, the problems are compounded by the high cost of credit obtained from conventional banks. The islands of Guernsey and Jersey have overcome this by issuing their own local currency. The Guernsey system is indicative. The modern currency system originated in the economically-depressed era following the Napoleonic wars as a means of financing necessary repairs to sea defences. Since interest payments on the public debt absorbed $80 \%$ of annual taxation income, the island government issued 'States notes' to circulate in parallel with official currency ( $£$ sterling). This provided an interest-free loan to finance the capital works programme. Today, the island government provides local banks with States notes in exchange for a similar sterling amount which is lodged in a deposit account in the States name. The island government receives interest-free credit plus interest accruing to the sum on deposit in the bank which is used to fund public works. The local currency is secure since each note is backed oneto-one by its British equivalent (Grubiak \& Grubiak 1960).

In Germany, since 2006 regional currencies have been issued in 16 regions as a cash alternative to the euro. These are conceived almost exclusively as schwundgeld (depreciating currency) that loses value on a predetermined timescale, with the intention of encouraging the money owners to spend quickly in order to boost the regional economy (Rösl 2006). At the city-region scale, Boyle (2002) has proposed a complementary money system for large cities such as London that would cover expenditure items such as transport and local economic exchanges within the urban region. The Oyster transport card introduced in London in 2003 is a current example that can 
also be used to purchase low-value non-transport items. By mid-2010, 34 million Oyster cards had been issued. Some forms of local money can have specific environmental goals. The $\mathrm{Nu}$ Spaarpas project in Rotterdam aimed to promote sustainable consumption by providing incentives (green points) for those who separated household waste for recycling, used public transport, or shopped locally. By the end of the two-year pilot in 2003, 10,000 households and 100 shops were participating and 1.5 million points had been issued (van Sambeek \& Kampers 2004). The advantages of a complementary currency are also recognised increasingly in the private sector where "nonbanks are playing increasingly significant roles in the financial world" (Mouatt 2010). Several major retailers (such as Marks and Spencer) have diversified into financial services (Welch \& Worthington 2007) as well as employing alternative currencies in the form of loyalty cards (such as Tesco clubcard, Nectar points, and Airmiles).

The benefits of a local currency to cashstrapped local councils appear unequivocal. A local currency reduces dependence on central government grants and expensive bank borrowings, funds necessary public projects, and boosts the local economy. National government would also benefit from increased tax revenues and lower social security expenditure. As proponents of local currencies in Wörgl and in the USA have found, however, a chief obstacle to implementation of local currency schemes remains central government resistance to the loss of control over the money supply. The force of this argument may be overstated, however. The amount of local currency in circulation would be minuscule compared to the national money supply and of almost no significance in relation to the volume of monetary transactions undertaken daily in the international financial system. By contrast, as the examples above have indicated, the impact of a local currency on the health of local economies and communities can be significant.

\section{Discussion and conclusion}

What then is the potential for local currencies as a response to the globalisation of capital? As we have seen, the growth of local currency sys- tems is related to the health of the local economy. In times of shortage of official currency, an alternative form of money represents a means of maintaining exchange relationships and preventing the collapse of a local economy by ensuring that a greater proportion of local income and savings circulate within the locality to generate local work, investment and local economic development. More generally, a local currency can promote the goals of subsidiarity and local autonomy by reducing dependency on a medium of exchange which must be imported from outside the region, whether in the form of central government disbursements or commercial bank loans. The value of a local currency is enhanced if it is accepted by local authorities in payment for rent, taxes and other services. Popular confidence in the currency may also be heightened if it is redeemable at par with national currency. However, in order to promote its use as a local medium of exchange, some form of discounting mechanism or negative interest rate may be appropriate. Use of a local currency could be complemented by other strategies designed to encourage satisfaction of local needs by local work using local resources including, for example, local purchasing and spending policies. One objection to the increased local autonomy stemming from use of a local form of money is the possibility that local authorities will abuse the power to issue currency and seek to spend their way out of financial crises. In the case of a currency backed by a national currency, however, over-issue would cause the local currency to decline in value relative to the national currency. This would result in a loss of revenue for the local authority obliged to redeem their currency at par. In the Salta province of Argentina during 1987 local currency was being traded at a $20 \%$ discount against national currency, but this was rectified by a temporary suspension in the issue of further local notes.

In practice no local economy can isolate itself from the vagaries of the national and international economic system. But it is equally myopic for political and economic decision-makers to ignore the adverse effects of the global economy on local places experiencing a net outflow of capital investment. A local currency cannot insulate the local economy from the negative effects of globalisation, but it can afford a degree of protec- 
tion against the spatially-insensitive currents of the international financial system. A combination of alternative financial institutions such as credit unions and local exchange trading systems, and a publicly-issued local currency has the potential to re-invigorate localities. As we have seen, in some instances the introduction of a local currency has the capacity to stimulate the social and economic regeneration of a community. The success of schemes such as that introduced in Wörgl and, more recently, in Ithaca suggests that the potential use of a local currency as a response to the globalisation of capital is, at minimum, worthy of further consideration - not least in those localities which currently are marginal to the mainstream of advanced capitalist society.

\section{References}

Angell N., 1930. The story of money. Cassell, London.

Bernanke B., 2009. Four questions about the financial crisis. Speech given at Morehouse College, Atlanta GA, April 14 2009. Available at http:/ / www.federalreservegov / newsevents/speech/bernanke20090414a.htm

Boyle D., 2002 (ed.). The money changers: currency reform from Aristotle to e-cash. Earthscan, London.

Cahn E. \& Rowe J., 1992. Time dollars. Rodale Press, Emmaus PA.

Cato M., 2006. Argentina in the red. International Journal of Complementary Currency Research, 10: 43-55.

Dauncey G., 1988. After the crash: The emergence of the rainbow economy. Greenprint, Basingstoke.

Dodd N., 1994. The sociology of money. Polity Press, Oxford.

Douthwaite R., 1996. Short circuit. Green Books, Totnes.

Eade J., 1997. Living the global city. Routledge, London.

Fisher I., 1933. Stamp scrip. Adelphi, New York.

Galbraith J.K., 1975. Money: Whence it came, where it went. Penguin, London.

Gesell S., 1958. The natural economic order. Peter Owen, London.

Greco T., 1994. New money for healthy communities. T.H. Greco, Tucson.

Greco T., 2001. Money - understanding and creating alternatives to legal tender. Chelsea Green Publishing Company, Vermont.

Grubiak O. \& Grubiak J., 1960. The Guernsey experiment. Omni Publishers, Hawthorn CA.
Jacob J., 2004. Hour town - Paul Glover and the genesis and evolution of Ithaca hours. International Journal of Complementary Currency Research, 8: 29-41.

Jacobs J., 1984. Cities and the wealth of nations. Penguin, Harmondsworth.

Kurtzman J., 1993. The death of money. Simon and Schuster, New York.

Linton M., 1986. Local currency. In: Ekins P. (ed.), The living economy: A new economics in the making. Routledge and Kegan Paul, London: 196-203.

Mouatt S., 2010. The case for monetary diversity. International Journal of Complementary Currency Research, 14: 17-28.

Pacione M., 1997a. Urban restructuring and the reproduction of inequality in Britain's cities: an overview. In: Pacione M. (ed.), Britain's cities: Geographies of division in urban Britain. Routledge, London: 7-60.

Pacione M., 1997b. Local exchange trading systems as a response to the globalisation of capitalism. Urban Studies, 34: 1179-1199.

Pacione M., 2004. Environments of disadvantage - the geography of persistent disadvantage in Glasgow. Scottish Geographical Journal, 120(1/2): 117-132.

Pacione M., 2009. Urban geography: A global perspective. Routledge, London.

Pearson R., 2003. Argentina's barter network: new currency for new times? Bulletin of Latin American Research, 22(2): 214-230.

Robertson J., 1989. Future wealth: A new economics for the 21st century. Cassell, London.

Reigel E., 1978. Flight from inflation: The monetary alternative. The Heather Foundation, Waterford VA.

Rösl G., 2006. Regional currencies in Germany - local competition for the Euro? Discussion Paper Series, 1: Economic Studies, 43. Deutschesbank, Frankfurt.

Seyfang G., 1994. The local exchange trading system. MSc thesis. School of Environmental Sciences, University of East Anglia.

Shaw-Taylor Y., 1998. Profile of social disadvantage in the 100 largest cities of the US 1980-1990/93. Cities, 15(5): 317-326.

Soddy F., 1935. The role of money. Harcourt, New York.

Solomon L., 1996. Rethinking our centralized monetary system. Praeger, Westport Conn.

Strange S., 1986. Casino capitalism. Basil Blackwell, Oxford.

Thorne L., 1996. Local exchange trading systems in the U.K. - a case of re-embedding? Environment and Planning A, 28: 1361-1376.

van Sambeek P. \& Kampers E., 2004. Nu-spaarpas: the sustainable incentive card. Stichting Points, Amsterdam.

Welch P. \& Worthington S., 2007. Banking at the checkout. Journal of Financial Services Marketing, 2(3): 230-245.

Williams C., 1996. Local exchange trading systems: a new source of work and credit for the poor and unemployed? Environment and Planning A, 28(7): 1395-1415. 